\title{
De Músculo Omohioideo a Músculo Escapulohioideo
}

\author{
From Omohyoid Muscle to Scapulohyoid Muscle
}

\author{
Nicolás Ernesto Ottone ${ }^{1,2}$; Claudia Andrea $\operatorname{Vargas}^{1,3} \&$ Mariano del Sol $^{1}$
}

OTTONE, N. E.; VARGAS, C. A. \& DEL SOL, M. De músculo omohioideo a músculo escapulohioideo. Int. J. Morphol., 35(2):740$744,2017$.

RESUMEN: Terminologia Anatomica se encuentra bajo constante revisión. A pesar de esto, continúan existiendo confusiones sobre el término correcto a utilizar pada cada estructura, en particular en español, ya que no existe una traducción oficial de Terminologia Anatomica en este idioma. Es conocido que el hueso antes llamado "omóplato" pasó a denominarse "escápula" pero aún no es oficial el cambio de nombre del músculo omohioideo, lo que se contrapone a una de las recomendaciones del Comité Federativo Internacional de Terminología anatómica que el término debe adaptarse al idioma vernáculo y su denominación debe concentrar la información y el papel descriptivo de la estructura en cuestión. Es por esto que hacemos un breve análisis del término M. omohyoideus (A04.2.04.003) Omohyoid en inglés y M. omohioideo en español. Se realizó una revisión en el diccionario de la Universidad de Salamanca y en textos antiguos de anatomía, además de observación directa por disección de cadáver. Sugiriendo renombrar el músculo, en Terminologia Anatomica, de M. omohyoideus a M. scapuhyoideus, M. Scapulohyoid, M. escápulohioideo.

PALABRAS CLAVE: Terminologia Anatomica; Escápula; Músculo omohioideo; Músculo escapulohioideo.

\section{INTRODUCCIÓN}

En la actualidad, la masificación en el acceso de la información científica obliga a los autores a presentar los resultados de sus investigaciones en un idioma científico común para que pueda ser comprendido por investigadores de distintos orígenes. Esta idea no es nueva, y son muchos los artículos que hacen referencia a esto, sin embargo continúan encontrándose inconsistencias en Terminologia Anatomica, la cual desde las asociaciones internacionales de anatomía, como la IFAA, o agrupaciones de morfológos, como los SILAT, se quiere establecer como el libro de terminología que todo investigador en el área debe respetar y utilizar para realizar sus comunicaciones científicas.

Desde los tiempos de Hipócrates (460-370 a.C.), el llamado "Padre de la Medicina", se comenzaron a presentar inconvenientes en el uso de términos anatómicos y fue uno de los primeros en realizar observaciones en este sentido. A Hipócrates lo sucedió Rufo de Efeso (110-180), quien en su libro "Sobre el nombre de las partes del cuerpo", también presentó objeciones a la terminología utilizada es ese entonces. Por su parte, Galeno (129-199) a través de sus estudios en animales, intentó crear e imponer una nomenclatura en griego y trasladar al estudio de la medici- na en humanos, manteniéndose estas enseñanzas durante más de mil años. Después de 13 siglos sin que se produjeran muchos avances en Anatomía, Andrés Vesalio, en 1543, publicó el libro «De humani corporis fabrica libri septem». Para Vesalio, la nomenclatura y sus términos debían ser simples, sencillos y que pudieran recordarse con facilidad mediante su asociación con cosas de la vida cotidiana (Vasquez \& del Sol, 2014).

Durante todos esos siglos, el número de términos anatómicos aumentó de manera exponencial. Algunas estructuras llegaron a tener varias denominaciones y la nomenclatura anatómica fue colmada de nombres, sinónimos y epónimos. En 1895 se publicó la Nomina Anatomica de Basilea, que permitió reducir los cantidad de términos anatómicos, de esta manera se continuó una adaptación de la nomina hasta alcanzar la Terminologia Anatomica actual.

El objetivo de este trabajo es sugerir el cambio del término músculo omohioideo por el de músculo escápulohioideo, para así, realizar un aporte al buen uso e implementación de TA en las ciencias morfológicas y también en las prácticas clínicas y quirúrgicas.

\footnotetext{
${ }^{1}$ Doctorado en Ciencias Morfológicas, Facultad de Medicina, Universidad de La Frontera, Temuco, Chile.

${ }^{2} \mathrm{CICO}$ - Centro de Investigación en Ciencias Odontológicas, Facultad de Odontología, Universidad de La Frontera, Temuco, Chile.

${ }^{3}$ Departamento de Educación Física, Deportes y Recreación, Facultad de Educación, Universidad de La Frontera, Temuco, Chile.
} 


\section{MATERIAL Y MÉTODO}

Para este trabajo se llevó a cabo una revisión bibliográfica de artículos científicos, se utilizó Terminologia Anatómica Internacional, del año 2001, publicada por la IFAA y la Sociedad Anatómica Española, con traducción al español, además de la "International Anatomical Terminology", publicada por la FIPAT, en el año 2011, correspondiendo únicamente a la traducción en inglés de los términos en latín.

Se realizó también, una búsqueda en MedLine con los términos "scapulohyoid", "scapulohyoid muscle" para corroborar si el término del músculo scapulohyoid era utilizado en artículos científicos referentes al músculo y no se encontraron resultados, sólo se encontraron estudios que utilizaban el término de músculo omohioideo ya que corresponde a la Terminología Anatómica actual.

Se realizó además, una búsqueda a través del sitio web del Diccionario Médico de la Universidad de Salamanca (Universidad de Salamanca, 2014), además de textos antiguos de anatomía y observación directa por disección de cadáver.

\section{RESULTADOS}

Término en TA para modificar: A04.2.04.003 $M$. omohyoideus.

omo: morfema

hyoideus: adjetivo, $2^{\text {a }}$ declinación, nominativo, masculino, singular

Diccionario Universidad de Salamanca:

omo gr., ōm(o)-, $\check{\omega} \mu \mathrm{o}$, 'hombro'

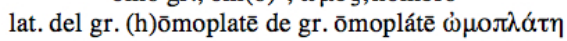

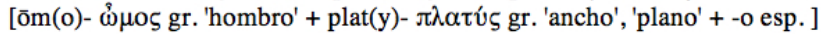

m. (Anat.) Cada uno de los dos huesos anchos, casi planos, situados a uno y otro lado de la espalda (en el hombro), donde se articulan los húmeros y las clavículas.

Leng. base: gr. Antigua. Docum. en 1493 en esp. en la forma homoplate. En gr. desde Hipócrates, s. V a.C., aparece en Celso como palabra griega, s. I d.C., docum. en lat. tardío (s. VI), debió pasar a lat. mediev. porque aparece en castellano mediev. homoplato, homplate. Etimol. 'parte plana del hombro'.

\section{[scapula(s) lat. 'escápula', 'omóplato']}

Leng. base: lat. Antigua. En lat. clás. además de omóplato significaba de forma más genérica 'hombro', 'parte alta de la espalda'; es probable su existencia en lat. mediev. a partir de derivados esp. como escapulario, docum. en 1246; como término culto anatómico se documenta en ingl. en 1578; para el valor de 'espalda' fue sustituido por spatula(m) de donde viene en esp. espalda.

\section{Propuesta: M. scapulohyoideus - M. Scapulohyoid - M. escapulohioideo}

scapulo: morfema (correspondiente al término: A02.4.01.001 - Scapula)

hyoideus: adjetivo, $2^{\text {a }}$ declinación, nominativo, masculino, singular

En Terminologia Anatomica Internacional, y ya establecido desde Nomina Anatomica de Basilea, el término omóplato fue reemplazado por el de escápula (A02.4.01.001 Scapula: sustantivo, $1^{\text {a }}$ declinación, nominativo, femenino, singular). El término original $M$. omohyoideus corresponde al músculo infrahioideo que se extiende desde el hueso omóplato al hueso hioides. De esta manera, al eliminarse el término omóplato y reemplazarlo por el de escápula, no tendría sentido seguir denominando a éste músculo como músculo omohioideo, sino que lo más adecuado sería comenzar a denominarlo como M. scapulohyoideus (latín), m. scapulohyoid (inglés) y M. escapulohioideo (español).

En los textos antiguos de anatomía y cirugía de humanos y animales, se encontraron ambos términos: Escápulohioideo y Omohioideo para denominar a la misma estructura muscular. Desde los años 1830 se utilizaron ambos términos; el término de escapulohioideo (Figs. 1.A, 1.B, 1.C, 1.D y 2.B. y 2.C) y Omohioideo (Figs. 2.A y 2.D).

En la Figura 3A se encuentra la imagen de la disección realizada en cadáver humano, y la Figura 3.B muestra la referencia esquemática. 
ARTERIAS DEL CUELLO.

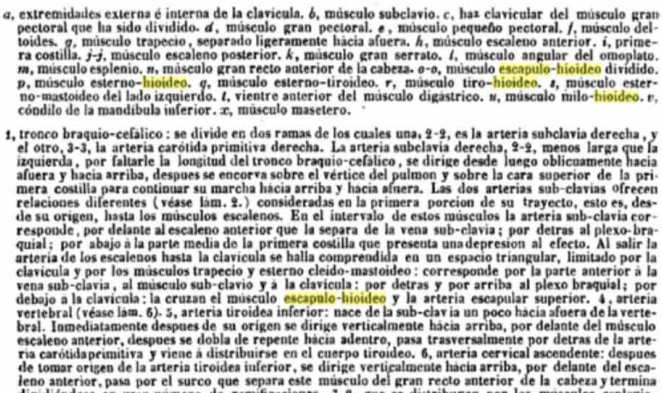

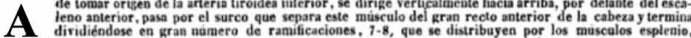

\section{M. VELPEAU ON THE LIGATURE OF ARTERIES.}

sterno-thyroid; then by the corresponding tid arteries, vessels which he deéms sellobe of the thyroid giand and the large dom to require ligature, except in $\begin{array}{lr}\text { as if bisected by the omo-hyoid towards } & \text { B.-EXTERNAL MAXILLARY. } \\ \text { the middle of the sub-hyoid region. Two } & \text { B. }\end{array}$ the middle of the sub-hyoid region. Two triangular spaces are thus formed. In the Operation.- Make an incision two inches lower or omo-tracheal, bcunded by the long parallel to the inner edge of the trachea, clavicle, and omo-hyoid, the ar- sterno-mastoid, and the middle of which
tery, hidden by the inner root of the corresponds with the great cornea of the sterno-mastoid, is very simple in its rela- corresponds with the great cornea of the tions, but very deeply placed. In the plitysma and fascia, separated the muscles, upper triangle, bounded by the omo- and laid bare the carotid artery, it become youe, sterno-linsto the sub-hyid region necessary to bear the sheath of this vessel above, and the scapulo-hyoid below, the the os hyoides, where the origin of the vessel is much more superficial, but it is artery sought for is found, and directect covered by a plexus of veins. However, inwards and upwards towards the subthe right carotid, shorter than the let, on maxillary glant. ably nearer the median line, and more su- The same method applies to the lingual, perficial throughour is tied with equal fa- wheh is mercly a ling

cility in both these triangular spaces. ated, and runs horizontally a little before
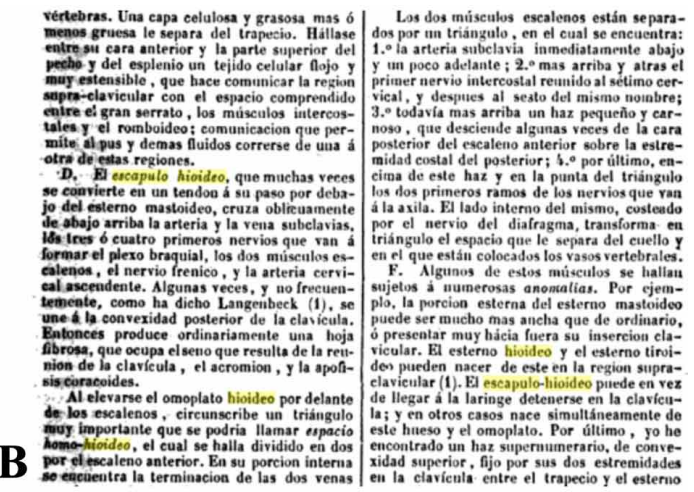

The second passes on the-upper part below the platysma muscles, on the outside of the digastrici muscles, and of the sub-maxillary gland, and terminates at the lower edge of the jaw, and also at its angle, being continuous with the stylo-maxillary ligament: inferiorly, this second layer of the cervical aponeurosis is situated below the sternomastoid muscles, and in front of the sterno-hyoid and thyroid muscles, then comes downward and terminates on the summit of the sternum, and on the posterior edge of the clavicle: it is attached laterally to the central tendon of the scapulo-hyoid muscle, and keeps it in its position; we must not blend this layer with the dense tissue which covers the carotid artery, and forms its stieath. This deep layer of the cervical aponeurosis is separated from the trachea and the thyroid gland, by the sterno-hyoid and thyroid muscles; but, on the outside of these, it gives off downward a secondary layer, which extends between these muscles and the trachea; this layer adheres above very intimately to the lower edge of the thyroid body, and is continuous below with the Deriosteum, which covers the posterior face of the sternum.

Fig. 1. A. Bonamy, M. C. Atlas de Anatomía Descriptiva del Cuerpo Humano. Madrid, Imprenta de J. Martin Alegria, 1848. B. Velpeau, A. Tratado Completo de Anatomía Quirúrjica General y Topográfica del Cuerpo Humano. Madrid, Imprenta de la Viuda de Jordan e Hijos, 1843. C. Velpeau, M. Analysis of Velpeau's New Elements of Operative Medicine, Ligature of Arteries. The Lancet, 2:517-55, 1833. D. Blandin, P. F. A Treatise on Topographical Anatomy: Or, The Anatomy of the Regions of the Human Body Considered in Its Relations with Surgery and Operative Medicine. New York, Moore \& Payne, 1834.

According to Mr. Richet, who has described with particular care the middle aponeurosis of the neck, this membrane sends ont from its lower surface, fibrous prolongations, which attach themselves to the trunks of the right and left brachiocephalic veins, and fix them to the upper bony rim of the chest. It receives then, in a reduplication, at the level of their opening into the subclavian vein, the internal and external jugular veins.

M. Richet, by reason of this arrangement, assigns to the extensor muscles of the omo-hyoid aponeurosis, the function of maintaining distended all the great veins of the region, and of thus rendering the circulation as easy as possible;

The third plane is that which exhibits the most intimate and most important connections with the vessels of the neck. It A assumes an arrangement entirelv peculiar. whose connections

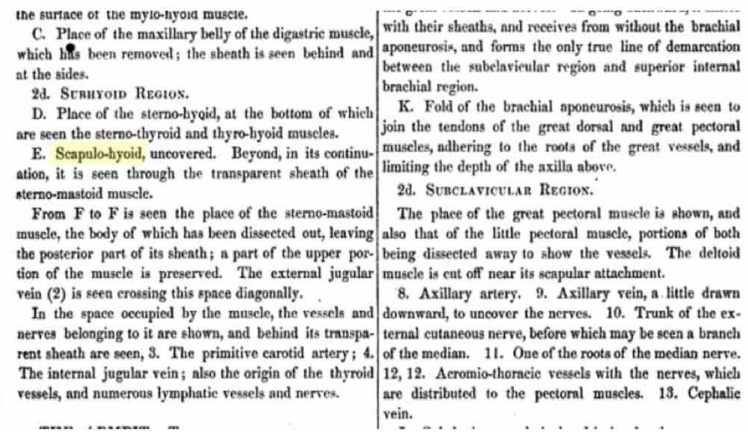

c. HYom noxr.

The hyoid bone gives insertion to the following muscles :-

a. By its body and its thyroid cornua-

1. Sterno-hyoid muscles.
2. Scapulo-hyoid muscles.

3. Mylo-hyoid muscles.

4. Genio-hyoid muscles.

5. Stylo-hyoid muscles.

6. Kerato-hyoid muscle

7. Transverse muscle of the hyoid bone.

b. By its branches (styloid cornua and styloid bones)-

1. Stylo-hyoid muscles.

3. Oocipito-styloid muscies.

Fig. 2. A. Monneret, M. Pathological Physiology. The continuous venous murmurs in the neck. Chicago Med. J., 25, 1868. B. Chauveau, A. The Comparative Anatomy of the Domesticated Animals. New York, D. Appleton, 1873. C. Maclise, J. The Plates of Maclise's Surgical Anatomy with Descriptions. Boston, J. P. Jewett, 1857. D. Velpeau, A. A. L. M. A Treatise on Surgical Anatomy: Or the Anatomy of Regions, Considered in Its Relations with Surgery: Illustrated by Plates Representing the Principal Regions of the Body. John Williams Sterling, 1830. 

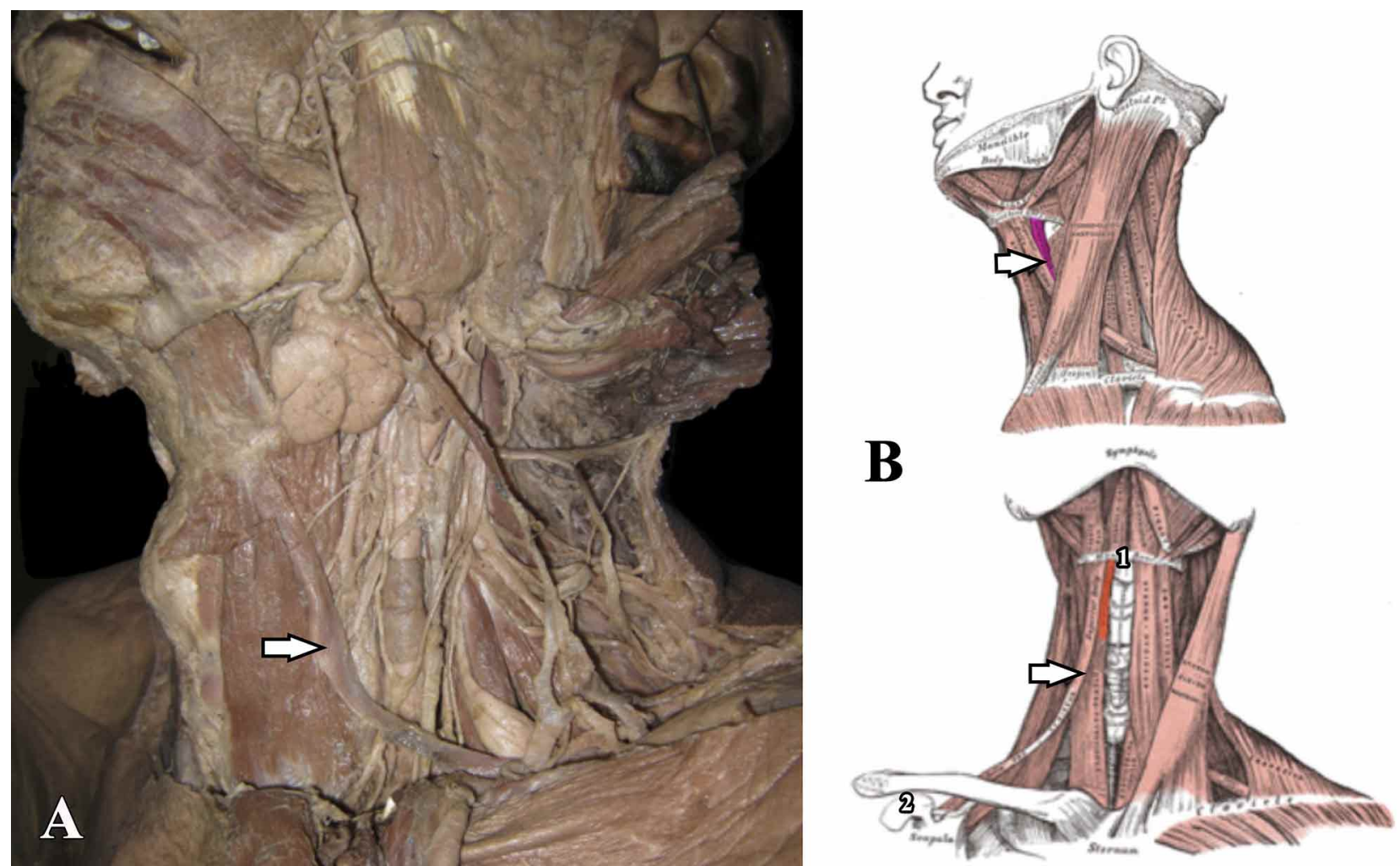

Fig. 3. A. Identificación del M. Omohoideo = M. escapulohioideo, en una disección cadavérica (flecha). B. Identificación del M. omohioideo (flecha). 1. Hioides. 2. Escápula (A. Gray, 1918).

\section{DISCUSIÓN}

La eliminación del término omóplato y su reemplazo por el de escapúla en Nomina Anatomica de Basilea (1895) también hubiera requerido la actualización del término M. omohioideo, pero esto no ocurrió. Esto se hubiera visto respaldado por las publicaciones anatómicas de la época, como por ejemplo los tratados anatómicos de Velpeau (1843) y Bonamy (1848), en los cuales ya era utilizado el término músulo escapulo-hioideo, término que reflotamos en este trabajo y que sugerimos como reemplazo del término $\mathrm{M}$. omohioideo. Además, esta propuesta acompaña uno de los preceptos básicos de Terminologia Anatomica que es el de asignar el nombre del término de la manera que representa más fielmente su morfología, ubicación y disposición. Es así que el término escapulohioideo identifica en forma precisa el origen e inserción de dicho músculo al momento de indicar que el origen del mismo es la escápula y no el omóplato, término antiguo y eliminado oficialmente de Nomina Anatomica de Basilea en 1895.

En Terminologia Anatomica se plantean problemas relacionados con la utilización de un mismo término para distintas estructuras, la traducción equivocada o diversas tra- ducciones con distintos significados del latín al idioma vernáculo (Cruz et al., 2010a; Matusz, 2011). Además de replanteamientos de los términos en latín para la correcta denominación de las estructuras (Vargas, et al., 2016) la falta de especificidad del término al encontrarse ausente su identificación al hipérnomino correspondiente, como así también una identificación morfológica errónea de la estructura que determina una denominación equivocada.

La nomenclatura se concibió como un sistema normalizado de términos exactamente definidos y dispuestos de acuerdo a ciertos principios de clasificación; esta es aprobada por una comisión científica y posteriormente debe ser aceptada por la comunidad profesional (Kachlik et al., 2008). Pero así como la anatomía, en la actualidad, debe ser directamente asociada a su aplicación clínica, la relación entre los anatomistas y los médicos clínicos y cirujanos debe ser estrecha, ya que de esta manera se logrará una mejor incorporación del nuevo lenguaje determinado desde la anatomía hacia el campo de la clínica y la cirugía (Kachlik et al.; Musil et al., 2015).

La recomendación de Terminologia Anatomica Internacional, en relación a la denominación de las estructuras anatómicas, es que los términos deben ser descriptivos, fáciles de recordar y armonizados, además de que deben ser 
unívocos y concisos, para poder alcanzar una precisión conceptual al momento de llevar a cabo la comunicación científica (Whitmore, 1999; Jiménez Gutiérrez, 2009).

En este sentido, y en relación a la oportunidad de comunicación y decisión de las modificaciones, es importante asegurar la participación de los anatomistas y los médicos en estos procesos de revisión (Pawlina \& Drake, 2009). Es fundamental una estrecha cooperación de los morfólogos con sus colegas clínicos para llegar a decisiones en común en cuanto a qué términos son necesarios modificar, incorporar o eliminar de Terminologia Anatomica (Musil et al., 2015). De esta saludable interacción nacerán procedimientos y métodos que permitan asegurar una adecuada revisión de los términos anatómicos para poder alcanzar en un futuro una nomina más adecuada y con términos, cuyas traducciones respeten el origen latino o en su defecto, se deba corregir el término del latín logrando que sean únicos, fáciles de recordar y que representen fielmente la estructura morfológica que denominan, escapando de las controversias permanentes que se suscitaron desde las primeras revisiones de la terminología a fines del siglo XIX y que continúan en la actualidad.

OTTONE, N. E.; VARGAS, C. A. \& DEL SOL, M. From omohyoid muscle to scapulohyoid muscle.Int. J. Morphol., 35(2):740-744, 2017.

SUMMARY: Terminologia Anatomica is under constant revision. Despite this, confutions about the correct term used for each structure still exist, particularly in spanish because an official translation in this language does not exist. It is widly known that the bone named before as omoplato ("shoulder blade") now it is call "scapula" but still, the change of the Omohyoid muscle, is not official, in opposition to Federal International Committee on Anatomical Terminology recommendation that the term has to adapt to the vernacular language and it denomination has to concentrate the information and the descriptive rol of the specific structure. Because of this, a short analysis of the term M. omohyoideus (A04.2.04.003), Omohyoid Muscle and M. omohioideo (in spanish) was made. Universidad de Salamanca dictionary, ancient anatomy texts and direct cadaver observation by dissection were used. Suggesting the muscle rename in Terminologia Anatomica, from M. omohyoideus to M. scapulohyoideus, M. Scapulohyoid, M. escapulohioideo.

KEY WORDS: Terminologia Anatomica; Scapula; M. omohyoid; M. Scapulohyoid.

\section{REFERENCIAS BIBLIOGRÁFICAS}

Blandin, P. F. A Treatise on Topographical Anatomy: Or, The Anatomy of the Regions of the Human Body Considered in Its Relations with Surgery and Operative Medicine. New York, Moore \& Payne, 1834.

Bonamy, M. C. Atlas de Anatomía Descriptiva del Cuerpo Humano. Madrid, Imprenta de J. Martin Alegria, 1848.

Chauveau, A. The Comparative Anatomy of the Domesticated Animals.
New York, D. Appleton, 1873.

Comité Federal sobre Terminología Anatómica (FCAT). Terminologia Anatomica. Terminología Anatómica Internacional. Madrid, Ed. Médica Panamericana, 2001.

Cruz, G. R.; Rodríguez, T. A.; Prates, J. C.; Losardo, R. J. \& Prates, N. E. V. B. Ibero-Latin-American Symposium of Morphological Terminology. General characteristics. Int. J. Morphol., 28(2):637-42, 2010a.

Cruz, G. R.; Rodríguez, T. A.; Prates, J. C.; Losardo, J. R. \& Barbato, V. N. Ibero-Latin-American Symposia Terminology. Anatomy, Histology and Embryology. Int. J. Morphol., 28(1):333-336, 2010 b.

Federative International Programme on Anatomical Terminologies (FIPAT). Terminologia Anatomica. $2^{\mathrm{a}}$ ed. New York, Thieme, 2011.

Gray, H. Anatomy of the human body. $20^{\text {th }}$ ed. Philadelphia, Lea \& Febiger, 1918. Disponible en: http://archive.org/stream/ anatomyofhumanbo1918gray\#page/398/mode/2up

Jiménez Gutiérrez, I. La sinonimia y la polisemia en la terminología anatómica: términos de ubicación y de relación de estructura anatómicas. Entreculturas, 1:579-96, 2009.

Kachlik, D.; Baca, V.; Bozdechova, I.; Cech, P. \& Musil, V. Anatomical terminology and nomenclature: past, present and highlights. Surg. Radiol. Anat., 30(6):459-66, 2008.

Maclise, J. The Plates of Maclise's Surgical Anatomy with Descriptions. Boston, J. P. Jewett, 1857

Matusz, P. Right/left symmetry of the intrahepatic distribution and terminology of the hepatic artery proper and the intrahepatic bile duct system: proposals to revise the Terminologia Anatomica. Surg. Radiol. Anat., 33(1):71-4, 2011.

Monneret, M. Pathological physiology. The continuous venous murmurs in the neck. Chicago Med. J., 25, 1868.

Musil, V.; Suchomel, Z.; Malinova, P.; Stingl, J.; Vlcek, M. \& Vacha, M. The history of Latin terminology of human skeletal muscles (from Vesalius to the present). Surg. Radiol. Anat., 37(1):33-41, 2015.

Pawlina, W. \& Drake, R. Moving forward with Terminologia Anatomica. Anat. Sci. Educ., 2(3):93, 2009.

Vargas, C. A.; Ottone, N, E. Contreras, M. \& Del Sol, M. ¿Facies o Impressio en el Bazo? Int. J. Morphol., 34(3):1002-8, 2016.

Vasquez, B. \& del Sol, M. The Terminologia Histologica in the Medical Sciences. Int. J. Morphol., 32(1):375-80, 2014.

Velpeau, A. A. L. M. A Treatise on Surgical Anatomy: Or the Anatomy of Regions, Considered in Its Relations with Surgery: Illustrated by Plates Representing the Principal Regions of the Body. John Williams Sterling, 1830.

Velpeau, A. A. L. M. Analysis of Velpeau's New Elements of Operative Medicine, Ligature of Arteries. The Lancet, 2:517-55, 1833.

Velpeau, A. A. L. M. Tratado Completo de Anatomía Quirúrjica General y Topográfica del Cuerpo Humano. Madrid, Imprenta de la Viuda de Jordan e Hijos, 1843.

Whitmore, I. Terminologia Anatomica: new terminology for the new anatomist. Anat. Rec., 257(2):50-3, 1999.

Dirección para correspondecia:

Nicolás Ernesto Ottone MD

$\mathrm{CICO}$ - Centro de Investigación en Ciencias Odontológicas

Facultad de Odontología

Universidad de La Frontera

Temuco - CHILE

Recibido : 10-02-2017

Aceptado: 25-04-2017

E-mail: nicolas.ottone@ufrontera.cl 